\title{
Permeability of Parkia gigantocarpa as Affected by Wood Anatomy
}

Edy Eime Pereira Baraúna, ${ }^{\mathrm{a}, *}$ José Tarcísio Lima, ${ }^{\mathrm{b}}$ Thiago Campos Monteiro, ${ }^{\mathrm{c}}$ Vaniele Bento dos Santos, ${ }^{\mathrm{a}}$ and Jean Henrique dos Santos ${ }^{\mathrm{c}}$

This study evaluated Parkia gigantocarpa wood from the Amazon rainforest for its permeability to air and liquid in the longitudinal direction. The influence of anatomical characteristics on the permeability of wood was characterized. Three trees were collected in the State of Pará, Brazil. Samples were converted into specimens and subjected to permeability tests and anatomical characterization. Permeability was obtained in the laboratory, and the results were compared with the permeability data estimated by a longitudinal flow model for hardwoods. The air permeability of wood was $140.2 \times 10^{-9} \mathrm{~m}^{3}$. [m. $\left.\left(\mathrm{N} . \mathrm{m}^{-2}\right) \cdot \mathrm{s}\right]^{-1}$ liquid permeability was $3.28 \mathrm{x}$ $10^{-9} \mathrm{~m}^{3}$. [m. $\left.\left(\mathrm{N} \cdot \mathrm{m}^{-2}\right) \cdot \mathrm{s}\right]^{-1}$. The fiber length and thickness of the cell wall had a direct and positive relationship with the permeability, whereas fiber width presented an inverse relationship with permeability. The vessel frequency and diameter did not influence the permeability of wood from the heartwood of $P$. gigantocarpa that presented high permeability and potential for easy wood drying and treatment.

Keywords: Air permeability; Liquid permeability; Fiber; Vessel; Faveira; Hardwood; Amazon

Contact information: a: Universidade Federal de Minas Gerais, Departamento de Engenharia Florestal, Montes Claros, Minas Gerais, Brasil; b: Universidade Federal de Lavras, Departamento de Ciências

Florestais, Lavras, Minas Gerais, Brasil; c: Universidade Federal do Paraná, Setor de Ciências Agrárias, Setor de Engenharia Florestal e Tecnologia, Curitiba, Paraná, Brasil

* Corresponding author: ebarauna@ica.ufmg.br

\section{INTRODUCTION}

The Brazilian Amazon was responsible for producing approximately 2.4 million $\mathrm{m}^{3}$ of hardwood lumber in 2019 (Food and Agriculture Organization 2021). In this region, more precisely in the states of Amazonas and Pará, Faveira (Parkia gigantocarpa Ducke) belonging to the Mimosaceae family is used to manufacture plywood, packaging, toys, furniture, decorative panels, boards, etc. People usually like this wood because of its characteristics, such as its moderately shiny surface and smoothness to the touch, besides its very light and soft wood processing (Mainieri and Chimelo 1989). Even though Faveira ( $P$. gigantocarpa) has several uses, research related to the technological properties of this species is very scarce.

Among the properties of wood, permeability is a paramount physical characteristic because it is a strong indicator of fluid displacement within forest species. This property is influenced by the material porosity, occlusion degree of the spaces where the fluid flows, diameter of empty spaces, fluid viscosity, and the interaction of fluid with the vessel wall of the material (Siau 1984; Jinman et al. 1991; Silva et al. 2010; Ahmed and Chun 2011; Sjökvist et al. 2020). In addition to the effect of these characteristics, the following can modify the permeability of wood: sample size (Bramhall 1971), direction of the air or liquid flow in the sample (Ahmed and Chun 2011; Monteiro et al. 2020), microwaves treatment 
(Nasswettrová et al. 2014), bio-treatment by wood-decaying fungi (Schwarze and Schuber 2011; Emaminasab et al. 2015), and changes in the temperature of the heat treatment (Jang and Kang 2019).

The relationship between water and wood has been studied for at least a century (Engelund et al. 2013); however, few studies evaluate the permeability of species native to the Amazon rainforest. Studying the influence of the technological properties of wood such as anatomical characteristics, e.g., number and diameter of vessels and fiber characteristics, may contribute to the better use of this wood as they are factors that influence the permeability of wood (Siau 1984; Ahmed and Chun 2011; Monteiro et al. 2017, 2021; Panigrahi et al. 2018; Jang et al. 2020).

Thus, by knowing the permeability of Faveira ( $P$. gigantocarpa), it is possible to estimate whether this wood is permeable to chemical preservatives and the removal of water during the drying process, and its adhesion potential for the manufacture of laminates and plywood (Hansmann et al. 2002; Panigrahi et al. 2018). In addition, the permeability of wood influences the production costs of finishes such as varnishes and paints, as well the behavior of wood when employed, especially when exposed to different conditions of relative humidity (Leggate et al. 2020). Therefore, the present study determined the longitudinal permeability of Faveira (Parkia gigantocarpa) and evaluated the influence of anatomical properties on air and liquid permeability.

\section{EXPERIMENTAL}

\section{Materials}

Woods of three beech trees (Parkia gigantocarpa Ducke) were obtained from a managed and certified natural forest (Forest Stewardship Council - FSC) belonging to the company Cikel Brasil Verde S/A. The forest is located in the municipality of Paragominas $\left(03^{\circ} 57^{\prime} \mathrm{S}\right.$ and $\left.48^{\circ} 64^{\prime} \mathrm{W}\right)$, in the state of Pará. The trees collected had a commercial height of 40 meters, and base logs of 2 meters in length were removed from each tree. After cutting the stem, the logs were sent to the company's sawmill. Three boards per tree were removed, with dimensions of $200 \mathrm{~cm}$ in length, $65 \mathrm{~cm}$ in width, and $3 \mathrm{~cm}$ in thickness.

\section{Sample Preparation}

Samples of random heartwood regions were obtained from each board. They were cut in a prismatic format, with dimensions of $260 \times 25 \times 25 \mathrm{~mm}$ in length, width, and thickness, respectively. The largest dimension was in the longitudinal direction of the wood. Then they were turned on a lathe tool in order to acquire a cylindrical shape (Fig. 1), with $20 \mathrm{~mm}$ in diameter, according to the methodology adopted in other studies (Silva et al. 2010; Baraúna et al. 2014; Rezende et al. 2017; Brito et al 2019). Subsequently, the samples were stored in a humidity-controlled chamber with a temperature of $20 \pm 2{ }^{\circ} \mathrm{C}$ and relative humidity of $60 \pm 5 \%$, until reaching constant mass.

The sample sides were waterproofed with low-flow epoxy resin in order to ensure only longitudinal flow. After curing the adhesive, the samples were sectioned on a circular saw to standardize their dimensions (20 x $50 \mathrm{~mm}$ in diameter and length, respectively), according to the permeability methodology (Silva et al. 2010; Baraúna et al. 2014). They were returned to the humidity-controlled chamber. From each board, 15 samples were produced, totaling 45 samples per tree. 


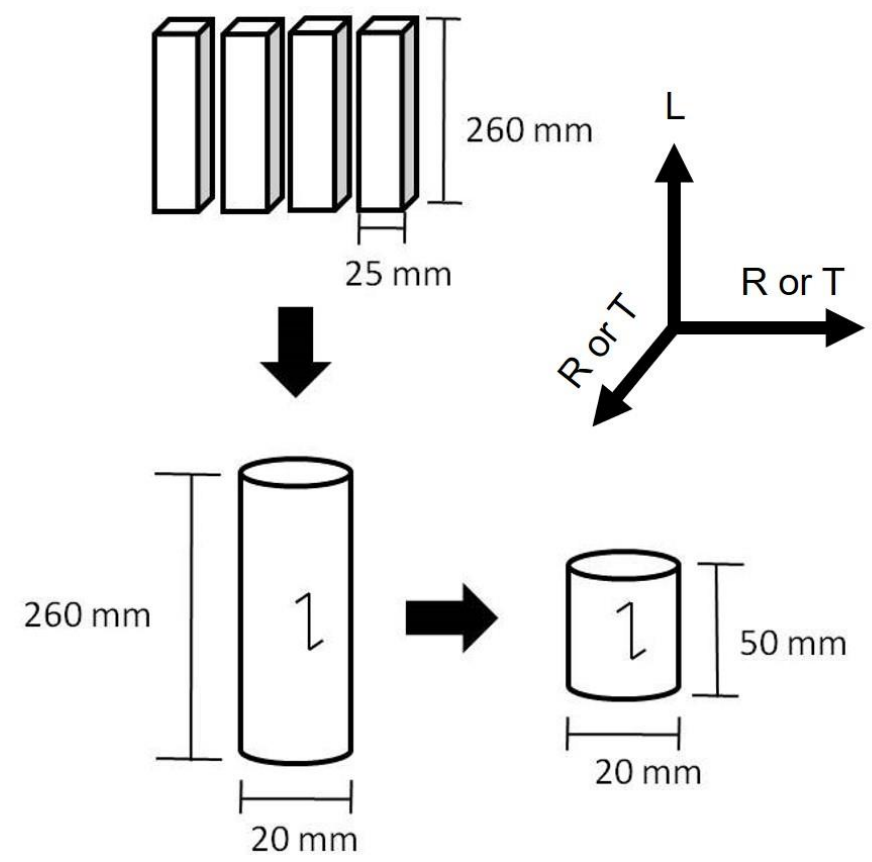

Fig. 1. Sampling preparation for the permeability test

\section{Permeability Test}

Permeability was measured as described (Silva et al. 2010; Baraúna et al. 2014; Rezende et al. 2017; Brito et al. 2019). The equipment for testing the atmospheric air permeability and liquid permeability was a flow meter and a burette, respectively.

For the atmospheric air permeability test, the device was equipped with three rotameters in order to measure the airflow in the samples. One edge of the sample was connected to a flow meter, and in the other, suction was applied. Airflow data, time (min) when the flow became constant, and pressure indicated by the vacuum pump manometer were recorded for the samples.

The liquid permeability was evaluated with a $50 \mathrm{~mL}$ graduated pipette, which replaced the rotameters. A set of stoppers was put, in which the samples were placed displaying one edge for suction through a common tapered glass, and the other connected to the burette as described (Silva et al. 2010; Baraúna et al. 2014; Rezende et al. 2017; Brito et al. 2019). The system was then subjected to suction. The passage time of $30 \mathrm{~mL}$ of distilled water by the sample was recorded with a digital timer. The pressure indicated by the vacuum pump manometer was measured.

\section{Permeability}

The gas permeability was determined according to Darcy's law (Eq. 1),

$$
K g=\frac{V L P}{t A \Delta P \bar{P}}
$$

where $K g$ is gas permeability $\left(\mathrm{cm}^{3} \text {. [cm.atm.s] }\right]^{-1}$ or $\mathrm{m}^{3}$. $\left.\left[\mathrm{m} .\left(\mathrm{N} \cdot \mathrm{m}^{-2}\right) . \mathrm{s}\right]^{-1}\right), V$ is volume of gas flowing through the species $\left(\mathrm{cm}^{3} \cdot \mathrm{s}^{-1}\right.$ or $\left.\mathrm{m}^{3} \cdot \mathrm{s}^{-1}\right), L$ is sample length $(\mathrm{cm}$ or $\mathrm{m}), P$ is pressure (atm or N. $\mathrm{m}^{-2}$ ), $\Delta P$ is pressure difference (atm or $\mathrm{N} . \mathrm{m}^{-2}$ ), $t$ is time (s), $A$ is cross-sectional area $\left(\mathrm{cm}^{2}\right.$ or $\left.\mathrm{m}^{2}\right)$, and $\bar{P}=$ average pressure in the specimen $\left(\right.$ atm or N.m $\left.{ }^{-2}\right)$.

Darcy's law was also used to determine the liquid permeability (Eq. 2),

$$
K=\frac{V L}{t A \Delta P}
$$


where $K$ is liquid permeability $\left(\mathrm{cm}^{3} \text {.[cm.atm.s }\right]^{-1}$ or $\mathrm{m}^{3}$. $\left.\left[\mathrm{m} .\left(\mathrm{N} . \mathrm{m}^{-2}\right) . \mathrm{s}\right]^{-1}\right), V$ is volume of liquid flowing through the species $\left(\mathrm{cm}^{3} \cdot \mathrm{s}^{-1}\right.$ or $\left.\mathrm{m}^{3} \cdot \mathrm{s}^{-1}\right), L$ is sample length $(\mathrm{cm} \mathrm{or} \mathrm{m}), t$ is time (s), $A$ is cross-sectional area $\left(\mathrm{cm}^{2}\right.$ or $\left.\mathrm{m}^{2}\right)$, and $\Delta P$ is pressure difference (atmospheres or N.m $\mathrm{m}^{-2}$.

\section{Anatomical Characterization}

After permeability tests, the anatomy of the samples was analyzed to observe the effect of the biometry of anatomical elements on the permeability of wood. The samples were cut in the dimensions of $1.5 \times 1.5 \times 2.0 \mathrm{~cm}$, in the tangential, radial, and longitudinal directions, respectively. For softening, the samples were heated in water at $70{ }^{\circ} \mathrm{C}$ for $24 \mathrm{~h}$. Due to the high resistance of the samples to cutting in the cross-section, they were boiled in nitric acid and distilled water, in the proportion of 1:10, for $10 \mathrm{~min}$.

The anatomical sections were cut using a sliding microtome, with thicknesses varying from 15 to $19 \mu \mathrm{m}$ in the tangential and radial directions and 21 to $23 \mu \mathrm{m}$ in the transversal direction. The anatomical description was performed according to the standards of the International Association of Wood Anatomists Committee - IAWA Committee (1989), using an optical microscope with an ocular magnification of 10x and an objective between 2.5 to 100 times, connected to the image analysis software Image-Pro Plus (Media Cybernetics, Silver Spring, USA). Thirty measurements on each face were taken for the following parameters: vessel diameter (VD) and vessel frequency (VF).

The macerated wood samples were prepared according to Franklin's method (1945). Fragments of the samples were placed in a container with a solution of glacial acetic acid and hydrogen peroxide in the proportion 1:1, allowing macerating for $48 \mathrm{~h}$ in an oven at $60{ }^{\circ} \mathrm{C}$. The slides were removed, and 30 measurements were collected for the fiber length (FL) and fiber width (FW). The fiber wall thickness (WT) was calculated considering the difference between fiber width and lumen diameter, divided by two.

\section{Data Analysis}

Descriptive analysis, coefficient of variation, and Pearson's correlation analysis were performed at a $95 \%$ probability level for the characteristics evaluated in the species wood. The statistical analysis of longitudinal permeability as a function of the anatomical structure was tested using a linear model for each parameter. The adjustments were made using statistical software, and the coefficient of correlation (R) was obtained for each adjustment. The model tested for regressions was the simple linear model, with a $95 \%$ confidence interval.

\section{RESULTS AND DISCUSSION}

\section{Anatomical Characterization}

Faveira ( $P$. gigantocarpa) had vessels per $\mathrm{mm}^{2}$ and vessel diameter (Table 1) close to those obtained by Détienne and Jacquet (1983) for the same species, with two vessels per $\mathrm{mm}^{2}$ and average vessel diameter of $200 \mu \mathrm{m}$. The total number of vessels per $\mathrm{mm}^{2}$ and their diameter are paramount as these parameters influence the impregnation and drying process of wood. The increase in the frequency and diameter of vessels facilitate the water output from the wood (Siau 1984; Monteiro et al. 2017). In addition, vessels have pits that communicate with ray cells or even other vessels, which also facilitate the air and liquid flow in the wood (Ahmed and Chun 2011; Monteiro et al. 2021). 
Table 1. Anatomical Characteristics of Faveira (Parkia gigantocarpa)

\begin{tabular}{|c|c|c|c|}
\hline \multicolumn{2}{|c|}{ Characteristic } & Mean & Coefficient of variation (\%) \\
\hline \multirow{4}{*}{ Anatomical } & Vessel Frequency $\left(\mathrm{mm}^{2}\right)$ & 5.7 & 18 \\
\cline { 2 - 4 } & Vessel diameter $(\mu \mathrm{m})$ & 217.4 & 8 \\
\cline { 2 - 4 } & Fiber length $(\mu \mathrm{m})$ & 1396 & 10 \\
\cline { 2 - 4 } & Wall thickness $(\mu \mathrm{m})$ & 3.1 & 14 \\
\cline { 2 - 4 } & Fiber width $(\mu \mathrm{m})$ & 28.5 & 12 \\
\hline
\end{tabular}

The mean values for fiber biometry, for instance, its length, width, and thickness of the cell wall (Table 1) were slightly lower than those obtained by Miranda and Castelo (2012), who found values for wall thickness of $5.44 \mu \mathrm{m}$, fiber width of $48.4 \mu \mathrm{m}$, and length equal to $1630 \mu \mathrm{m}$, when studying Faveira ( $P$. gigantocarpa). These variations in the biometry of anatomical elements for the same species can occur as it is native to the Amazon rainforest. However, the variation in results needs further investigation, especially as both studies focused on native wood, which is much less variable than plantations created, for example. The genetic material, development environment of the tree, and interaction between these parameters affect the wood quality of this species (Zobel and Van Buijtenen 1989). Figure 2 presents the cross-section of Parkia gigantocarpa wood, with vessel distribution and visualization of the early and late wood of the species. These factors were consistent with the variations (CV \%) obtained for the anatomical structures of the species.

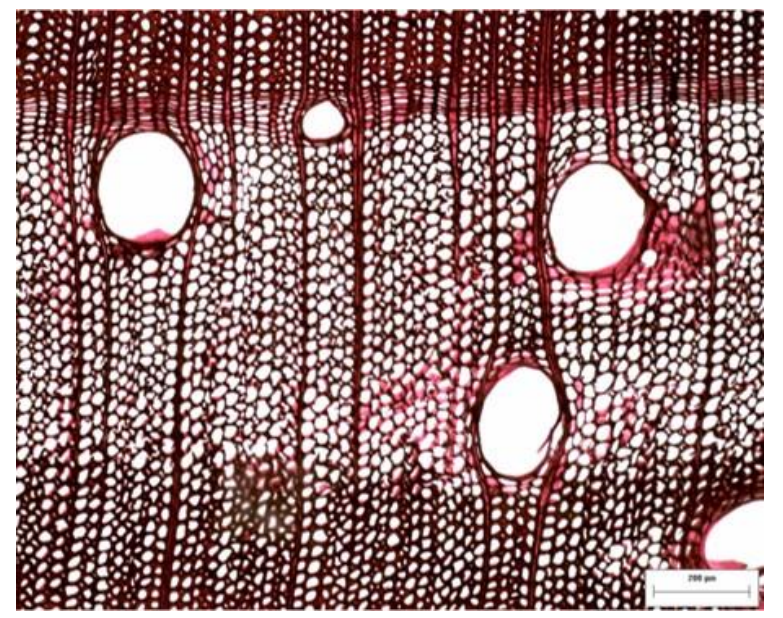

Fig. 2. Cross-section of Parkia gigantocarpa wood

\section{Permeability of Wood}

The mean air permeability of $P$. gigantocarpa (Table 2) was higher than the wood of different species of Eucalyptus, with mean values of $69.7 \mathrm{~cm}^{3}(\mathrm{~cm} . \mathrm{atm} . \mathrm{s})^{-1}$ (Rezende et al. 2017) and wood from species native to the Amazon, such as Brosimum parinarioides, with mean value of $63.7 \mathrm{~cm}^{3}$.(cm.atm.s) ${ }^{-1}$ (Baraúna et al. 2014). Nonetheless, Faveira ( $P$. gigantocarpa) exhibited values close to the longitudinal air permeability of coniferous wood (Pinus elliottii), between $119.4 \times 10^{-9}$ and $156.9 \times 10^{-9} \mathrm{~m}^{3} / \mathrm{m} .\left(\mathrm{N} / \mathrm{m}^{2}\right)$.s (Silva 2007). These results indicate the potential of Parkia gigantocarpa heartwood for drying and treatment with preserved products. 
Table 2. Mean Values of Air and Liquid Permeability of Faveira (Parkia gigantocarpa)

\begin{tabular}{|c|c|c|c|}
\hline \multicolumn{2}{|c|}{ Characteristic } & Mean & Coefficient of variation (\%) \\
\hline \multirow{6}{*}{ Permeability } & Air & & \\
\hline & $\mathrm{cm}^{3} \cdot(\mathrm{cm} \cdot \mathrm{atm} \cdot \mathrm{s})^{-1}$ & 142 & \multirow{2}{*}{44} \\
\hline & $\mathrm{m}^{3} \cdot\left[\mathrm{m}\left(\mathrm{N} \cdot \mathrm{m}^{-2}\right) \cdot \mathrm{s}\right]^{-1}$ & $140.2 \times 10^{-9}$ & \\
\hline & Liquid & & \\
\hline & $\mathrm{cm}^{3} \cdot(\mathrm{cm} \cdot \mathrm{atm} \cdot \mathrm{s})^{-1}$ & 3.323 & \multirow{2}{*}{113} \\
\hline & $\mathrm{m}^{3} \cdot\left[\mathrm{m}\left(\mathrm{N} \cdot \mathrm{m}^{-2}\right) \cdot \mathrm{s}\right]^{-1}$ & $3.28 \times 10^{-9}$ & \\
\hline
\end{tabular}

The samples evaluated were obtained just from heartwood, as sapwood was not observed in the logs. This region in juvenile Eucalyptus reforestation trees often has low permeability or presents very low values (Silva et al. 2010; Brito et al. 2019). Factors such as elevated levels of extractives in addition to the obstruction of vessels with tyloses may affect the permeability in this region (Bailey and Preston 1969; Micco et al. 2016). Permeable heartwood from native species can be an interesting wood for manufacturing solid products with high-added value, such as furniture, floors, frames, and others.

Presenting the same behavior, the liquid permeability of Faveira ( $P$. gigantocarpa) (Table 2) exhibited higher values than Eucalyptus $\left(1.470 \mathrm{~cm}^{3} .(\mathrm{cm} . \mathrm{atm} . \mathrm{s})^{-1}\right)$ and Brosimum parinarioides woods $\left(2.070 \mathrm{~cm}^{3} .(\mathrm{cm} . \mathrm{atm} . \mathrm{s})^{-1}\right)$ (Baraúna et al. 2014; Rezende et al. 2017). Despite the homogeneity of mature (non-juvenile) wood, there are variations in wood properties for the longitudinal and radial directions of the tree. These differences resulted in variations in the properties of the wood and, consequently, in the permeability values for the species. Other studies with the same methodology also presented a higher coefficient of variation (Baraúna et al. 2014; Rezende et al. 2017).

Studies on the permeability of hardwood have mainly reported values for the longitudinal direction and report difficulties in measuring this parameter for the radial and tangential directions (Isaacs et al. 1971; Silva et al. 2010; Baraúna et al. 2014; Rezende et al. 2017; Brito et al. 2019). The methodology used in this research has limitations; using distilled water, for example, could bond the hydroxylic sites in wood, reducing drastically the liquid flow through the wood. In addition, air bubbles could occur inside the wood and reduce permeability. This situation occurs as wood is a hygroscopic material, therefore presenting great affinity with water (Siau 1984; Engelund et al. 2013). This effect may explain the low values of liquid permeability. On the other hand, studies with other methodologies presented water movement in the longitudinal direction twice greater than in the radial direction and three times greater than in the tangential direction (Monteiro et al. 2020). In addition, Tanaka et al. (2010) used the permeameter apparatus and ultrasonic treatment, and they also found higher values in the radial direction when compared to the tangential direction on Douglas-fir wood permeability.

\section{Permeability Relationship and Anatomical Structure}

The anatomical characteristics of Faveira ( $P$. gigantocarpa) may explain the values of air and liquid permeability. Table 3 displays the correlations between anatomical structure, fiber biometry, vessel frequency, and diameter with air and liquid permeability of Faveira ( $P$. gigantocarpa) wood. The correlations have a higher effect on fibers when compared to vessels on the air and liquid flow in the wood. 
Table 3. Pearson's Correlation Matrix for the Anatomical Characteristics of Parkia gigantocarpa Wood

\begin{tabular}{|c|c|c|c|c|c|c|c|}
\hline Characteristics & $F L$ & $W T$ & $F W$ & $A P$ & $L P$ & $V F$ & $V D$ \\
\hline Air Permeability & 0.28 & 0.18 & -0.66 & 1.00 & 0.13 & -0.10 & -0.06 \\
\hline Liquid Permeability & 0.30 & 0.11 & -0.11 & 0.13 & 1.00 & -0.04 & -0.09 \\
\hline
\end{tabular}

Note: $F L$ is fiber length, $W T$ is wall thickness, $F W$ is fiber width, $A P$ is air permeability, $L P$ is liquid permeability, $V F$ is vessel frequency, and $V D$ is vessel diameter.

Fiber width was the parameter that most negatively affected air and liquid permeability of Parkia gigantocarpa wood (Table 3). Probably, the wider the fiber, the less space is left for liquid and air flow in the wood. In addition, fibers have smaller pits than other structures, and they are anatomical structures that do not have openings such as perforation plates in the vessels to help permeability. Nevertheless, fiber length and thickness of the cell wall positively contributed to the air and liquid flow in wood (Table 3). In another study with Amapá wood, from the Amazon, the fiber length, fiber width, and thickness of the cell wall presented a positive correlation with liquid and air permeability (Baraúna et al. 2014). Using another methodology to evaluate the liquid flow in the juvenile Eucalyptus urophylla and Corymbia citriodora reforestation wood, fiber length and width also presented a positive correlation with wood drying (Monteiro et al. 2017). However, the thickness of the cell wall also reduced the drying of Eucalyptus and Corymbia woods.

The vessel frequency and diameter presented a low correlation with air and liquid permeability in $P$. gigantocarpa wood (Table 3). Thus, more studies on vessels or porosity quality in wood are needed, as well as adaptations in the methodology, such as testing the samples at different initial moisture levels or with different sizes. Overall, the literature reports the importance of air and liquid flow mainly in the vessels, presenting less flow in the rays and fibers (Siau 1984; Engelund et al. 2013). Further studies on the effect of tyloses obstructing the vessel and pits, especially vessel-ray and intervessel pits, are also needed. In addition to the inherent complexity of the wood raw material, wood processing, e.g., heat-treating temperature conditions (Jang and Kang 2019), microwaves treatment (Nasswettrová et al. 2014), and bio-treatment by wood-decaying fungi (Schwarze and Schuber 2011; Emaminasab et al. 2015), can influence its permeability. The data in this study combined with new research in the area of wood processing can make little-known species, such as Parkia gigantocarpa, interesting for the forest-based industry. This report can contribute to an entire production chain based on sustainable forest management in the Amazon.

\section{CONCLUSIONS}

1. The air permeability of Parkia gigantocarpa wood was approximately 43 times higher than for the liquid permeability.

2. Values for permeability of wood of Parkia gigantocarpa were slightly higher than for the permeability of wood of others hardwood. These indicate the potential of this wood for easy drying and treatment. 
3. The increase in fiber length and thickness of the cell wall favored permeability. This behavior was the opposite of that presented for fiber width.

4. The vessel frequency and diameter exhibited low correlations with air and liquid permeability.

\section{ACKNOWLEDGMENTS}

The authors thank the Research Development Foundation - FUNDEP (Project 27506) from Universidade Federal de Minas Gerais and the Pró-Reitoria de Pesquisa e Pós-graduação from Universidade Federal do Paraná for the financial support. This study was performed with the support of the Coordination for the Improvement of Higher Education Personnel - (CAPES) - Brazil - Financing Code 001. The authors also thank the company Cikel Brasil Verde S/A for providing wood samples for the tests.

\section{REFERENCES CITED}

Ahmed, S. A., and Chun, S. K. (2011). "Permeability of Tectona grandis L. as affected by wood structure," Wood Sci. Technol. 45(3), 487-500. DOI: 10.1007/s00226-0100335-5

Bailey, P. J., and Preston, R. D. (1969). "Some aspects of softwood permeability. I. Structural studies with Douglas fir sapwood and heartwood," Holzforschung 23(4), 113-120. DOI: 10.1515/hfsg.1969.23.4.113

Baraúna, E. E. P., Lima, J. T., Vieira, R. S., Silva, J. R. M., and Monteiro, T. C. (2014). "Effect of anatomical and chemical structure in the permeability of "Amapá" wood," Cerne 20(4), 529-534. DOI: 10.1590/01047760201420041501

Bramhall, G. (1971). "The validity of Darcy's law in the axial penetration of wood," Wood Sci. Technol. 5(2), 121-134. DOI: 10.1007/BF01134223

Brito, A. S., Vidaurre, G. B., Oliveira, J. T. S., Missia da Silva, J. G., Rodrigues, B. P., and Carneiro, A. D. C. O. (2019). "Effect of planting spacing in production and permeability of heartwood and sapwood of eucalyptus wood," Floresta e Ambiente 26(SPE1). DOI: 10.1590/2179-8087.037818

Détienne, P., and Jacquet, P. (1983). Atlas d'Identification des Bois de l'Amazonie et des Régions Voisines, Centre Technique Forestier Tropical, Paris.

Emaminasab, M., Tarmian, A., and Pourtahmasi, K. (2015). "Permeability of poplar normal wood and tension wood bioincised by Physisporinus vitreus and Xylaria longipes," Int Biodeter Biodegr 105, 178-184. DOI: 10.1016/j.ibiod.2015.09.003

Engelund, E. T., Thygesen, L. G., Svensson, and S., Hill, C. A. S. (2013). "A critical discussion of the physics of wood-water interactions," Wood Sci. Technol. 47, 141161. DOI: $10.1007 / \mathrm{s} 00226-012-0514-7$

Food and Agriculture Organization (2021). "Forestry Production and Trade," http://www.fao.org/faostat/en/\#data/FO. Accessed 09/02/2021.

Franklin, G. L. (1945). "Preparation of thin sections of synthetic resins and wood-resin composites, and a new macerating method for wood," Nature 155(3924), 51-51. DOI: $10.1038 / 155051 \mathrm{a} 0$

Hansmann, C., Gindl, W., Wimmer, R., and Teischinger, A. (2002). "Permeability of 
wood - A review," Wood Research 47(4), 1-16.

Isaacs, C. P., Choong, E. T., and Fogg, P. J. (1971). "Permeability variation within a cottonwood tree," Wood Science 3(4), 231-237.

Jang, E. S., and Kang, C. W. (2019). "Changes in gas permeability and pore structure of wood under heat treating temperature conditions," J. Wood Sci. 65(1), 37. DOI: 10.1186/s10086-019-1815-3

Jang, E., Yuk, J. H., and Kang, C.W. (2020). "An experimental study on change of gas permeability depending on pore structures in three species (hinoki, Douglas fir, and hemlock) of softwood," J. Wood Sci. 66(1), 1-12. DOI: 10.1186/s10086-020-01925-9

Jinman, W., Chengyue, D., and Yixing, L. (1991). "Wood permeability," J. Northeast For. Univ. 2(1), 91-97. DOI: 10.1007/BF02874797

Leggate, W., McGavin, R. L., Miao, C., Outhwaite, A., Chandra, K. A., Dorries, J., Kumar, C., and Knackstedt, M. (2020). "The influence of mechanical surface preparation methods on southern pine and spotted gum wood properties: Wettability and permeability," BioResources 15(4), 8554-8576. DOI: 10.15376/biores.15.4.85548576

Mainieri, C., and Chimelo, J. P. (1989). Fichas de Características das Madeiras Brasileiras, IPT, São Paulo.

Micco, V., Balzano, A., Wheeler, E. A., and Baas, P. (2016). "Tyloses and gums: A review of structure, function and occurrence of vessel occlusions," IAWA Journal 37(2), 186-205. DOI: 10.1163/22941932-20160130.

Miranda, M.C., and Castelo, P.A.R. (2012). "Avaliações anatômicas das fibras da madeira de Parkia gigantocarpa Ducke," Rev Ciência da Madeira (Brazilian J Wood Sci 3(2), 80-88. DOI: 10.12953/2177-6830.v03n02a07

Monteiro, T. C., Lima, J. T., Hein, P. R. G., Silva, J. R. M., Trugilho, P. F., and Andrade, H. B. (2017). "Effect of wood anatomical elements in log drying of Eucalyptus and Corymbia," Scientia Forestalis 45(115), 493-505.

Monteiro, T. C., Lima, J. T., Abreu Neto, R., and Ferreira, C. A. (2021). "Importance of pits in Corymbia citriodora (Hook.) K.D. Hill \& L.A.S. Johnson (Myrtaceae) wood permeability," Floresta e Ambiente 28. DOI: 10.1590/2179-8087-floram-2020-0012

Monteiro, T. C., Lima, J. T., Silva, J. M., Rezende, R. N., and Klitzke, R. J. (2020). "Water flow in different directions in Corymbia citriodora wood," Maderas Ciencia y Tecnologia 22(3). DOI: 10.4067/S0718-221X2020005000312

Nasswettrová, A., Šmíra, P., Zejda, J., Nikl, K., and Sebera, V. (2014). “Axial permeability of beech wood treated by microwave heating for distilled water," Wood Research 59, 25-37.

Panigrahi, S., Kumar, S., Panda, S., and Borkataki, S. (2018). "Effect of permeability on primary processing of wood," J. Pharmacogn. Phytochem. 7, 2593-2598.

Rezende, R. N., Lima, J. T., de R. e Paula, L. E., Hein, P. R. G., and da Silva, J. R. M. (2017). "Wood permeability in Eucalyptus grandis and Eucalyptus dunnii," Floresta e Ambiente 25(1). DOI: 10.1590/2179-8087.022815

Schwarze, F. W. M. R., and Schuber, M. (2011). "Physisporinus vitreus: A versatile white rot fungus for engineering value-added wood products," Appl. Microbiol. Biotechnol. 92(3), 431-40. DOI: 10.1007/s00253-011-3539-1.

Siau, J. F. (1984). Transport Processes in Wood, Springer, New York.

Silva, M. R., Machado, G. de O., Deiner, J., and Calil Jr., C. (2010). "Permeability measurements of Brazilian eucalyptus," Mater. Res. 13, 281-286. DOI: 10.1590/S1516-14392010000300002 
Silva, M. R. (2007) Determinação da Permeabilidade em Madeiras Brasileiras de Florestas Plantadas, Ph.D. Dissertation, Universidade de São Paulo, Brazil.

Sjökvist, T., Blom, Å., and Ahmed, S. A. (2020). "Liquid water absorption in coated norway spruce: Impact of heartwood, sapwood, density and weather exposure," Maderas Ciencia y Tecnologia 22(3). DOI: 10.4067/S0718-221X2020005000308

Tanaka, T., Avramidis, S., and Shida, S. (2010). "A preliminary study on ultrasonic treatment effect on transverse wood permeability," Maderas Ciencia y Tecnologia 12(1), 3-9. DOI: 10.4067/S0718-221X2010000100001

Zobel, B. J., and Van Buijtenen, J. P. (1989). Wood Variation: Its Causes and Control, Springer, Berlin.

Article submitted: February 6, 2021; Peer review completed: March 14, 2021; Revised version received and accepted: May 10, 2021; Published: May 17, 2021.

DOI: 10.15376/biores.16.3.4924-4933 